\title{
SPATIAL DISTRIBUTION OF BTEX AND INORGANIC POLLUTANTS DURING SUMMER SEASON IN YALOVA, TURKEY
}

\author{
ROZKŁAD PRZESTRZENNY BTEX I ZANIECZYSZCZEŃ \\ NIEORGANICZNYCH W SEZONIE LETNIM W YALOVA, TURCJA
}

\begin{abstract}
The objective of this research is to determine the atmospheric concentrations and spatial distribution of benzene (B), toluene (T), ethylbenzene (E) and xylenes (X) (BTEX) and inorganic air pollutants $\left(\mathrm{O}_{3}, \mathrm{NO}_{2}\right.$ and $\mathrm{SO}_{2}$ ) in the Yalova atmosphere during summer 2015. In this study, a combination of passive sampling and Geographical Information System-based geo-statistics are used with spatial statistics of autocorrelation to characterise the spatial pattern of the quality of air based on concentrations of these pollutants in Yalova. The spatial temporal variations of pollutants in the air with five types of land-use, residence, rural, highway, side road and industrial areas were investigated at 40 stations in Yalova between $7^{\text {th }}$ August 2015 and $26^{\text {th }}$ August 2015 using passive sampling. An inverse distance weighting interpolation technique was used to estimate variables at an unmeasured location from observed values at nearby locations. The spatial autocorrelation of air pollutants in the city was investigated using the statistical methods of Moran's I in addition to the Getis Ord Gi. During the summer, highway and industrial sites had higher levels of BTEX then rural areas. The average concentration of toluene was measured to be $5.83 \mu \mathrm{g} / \mathrm{m}^{3}$ and this is the highest pollutant concentration. Average concentrations of $\mathrm{NO}_{2}, \mathrm{O}_{3}$ and $\mathrm{SO}_{2}$ are $35.64,84.23$ and $3.95 \mu \mathrm{g} / \mathrm{m}^{3}$, respectively. According to the global results of Moran's I; $\mathrm{NO}_{2}$ and BTEX had positive correlations on a global space at a significant rate. Moreover, the autocorrelation analysis on the local space demonstrated significant hot spots on industrial sites and along the main roads.
\end{abstract}

Keywords: air quality, core pollutants, GIS, IDW, spatial autocorrelation

\section{Introduction}

Rapid increase in population, uncoordinated urbanisation in addition to industrialisation are the primary contributing factors to air pollution in European urban areas. Despite essential developments and also improvements regarding solutions to air pollution in many European urban areas over the last three decades, this problem still stands [1]. The rapid growth in road traffic and urban populations has led to the rise in quantity of

\footnotetext{
${ }^{1}$ Environmental Engineering Department, Corlu Engineering Faculty, Namik Kemal University, Silahtaraga 3, 59860 Corlu, Tekirdag, Turkey

${ }^{2}$ Geography Department, Balikesir University, Çağış Yerleşkesi, Bigadiç Yolu 17 km, 10463 Balikesir, Turkey, phone 902666121000 , fax 902666121215

${ }^{3}$ The Ministry of Environment and Urban Planning, Yalova Provincial Offices, Adnan Menderes Neighborhood, Rahmi Ustel 2, 77200 Yalova, Turkey

* Corresponding author: stagil@balikesir.edu.tr
} 
pollutants. However, worsening of the conditions related with air pollution in urban areas also causes a decrease on the health conditions and welfare of the residents together with the ecosystems lived around [2-4].

Due to this there is a need for all European cities to evaluate their air quality. This is stipulated in the new directive on air quality [5]. According to this directive it is necessary for the member states to provide information to people by means of collecting, exchanging and disseminating related current data and statistics so that the society can better understand the impacts and effects caused by air pollution which would also lead to the development of better policies. To be able to protect the residents and their surrounding at a larger scale, it is essential to try to eradicate the emissions of air pollutants at where they are brought about by identifying the measures to be taken and implement them at the same time to reduce the emission at local, national and eventually at societal level. The latest forecasts of World Health Organisation and the European Commission has put forward that 400,000 deaths of premature babies could be related with the pollution in the air in the surrounding area in years of 2010 and 2012 in Europe [6].

Generally, studies on air pollution are carried out with the data collected from continuous monitoring stations in urban areas $[4,7]$. Although this approach is widely used, many research on air pollution has shown signs of the existence variability between intra urban areas and areas of street scale, which may be important for air quality indicators [8] and therefore does not represent environmental exposure. Furthermore, according to Wheeler et al. [8], air pollution data from fixed monitoring stations cannot be used directly as true indicators of population exposure. Therefore, in order to understand the effects of atmospheric pollutants as a result of the exposure of populations, investigating the situation of intra-urban areas is of high importance. Diffusive sampling is also another way to evaluate the quality of the air regarding pollution. As for the advantages of passive sampling; it is simpler and less expensive than automatic monitoring stations. It is well known fact that patterns of air pollution related with space are generally the consequence of physical and cultural changes in progress on our planet. Spatial patterns can be used in showing the way air pollutants are distributed at random or give times. They can be in forms of cluster, dispersion and shuffle. However, it is not possible with this analysis to know when there are only a few stations in the city. To analyse the spatial pattern of air pollution we need a greater number of samples. In this case, passive sampling is convenient as it allows for mapping of the urban and rural air quality $[9,10]$.

Providing new ways of analysis in spatial distributions and patterns of air pollution concentrations regarding space has been possible with Geographical Information Systems (GIS) and geo-statistics [4]. According to literature, research on air pollution is generally brought about by methods of distance-weighting [11, 12] and kriging [13-15]. In fact, interpolation is aimed to distinguish among spatial patterns of phenomenon by making predictions on the values at un-sampled areas using nearby sampling points. The inverse distance weighting (IDW) method presents more weight according to the distance; more for closer and less for distant locations, however, in kriging method which is a regression-based technique, the values are estimated in un-sampled areas. And this technique uses weights which reflect the correlation from a sample point to the one to be estimated. These techniques also provide very useful knowledge about the structure of air quality patterns. There is no clear agreement on any approach whether it could be accepted optimal globally, although a number of studies compare these techniques [16-18]. No matter which method, environmental health agencies are increasingly using GIS 
technology to protect the health of populations and understand the impacts of the air pollution on human health. Although, these geostatistical techniques are widely used, they cannot determine the status of spatial correlation; whether affirmative or adverse. Spatial autocorrelation is all about observations; as it is also defined as the observation by spatial adhesion. In cluster identification, there are some methods that has gained importance after the localization of global solutions on spatial auto-correlation; one of the important one of them is the use of spatial data analysis [4]. Local Getis-Ord is one of these solutions together with Moran's Indicators [19].

In Turkey, the basic causes of air pollution in urban areas can be sorted as; rapid increases in the number of people living in, urbanization without plan and also industrialization. It is well documented that benzene (B), toluene (T), ethylbenzene (E) and xylene (X) (BTEX), nitrogen dioxide $\left(\mathrm{NO}_{2}\right)$, ozone $\left(\mathrm{O}_{3}\right)$ and sulfur dioxide $\left(\mathrm{SO}_{2}\right)$ can adversely affect human health. Volatile Organic Compounds (VOCs) are a group commonly referred to as BTEX, which includes benzene, toluene, ethylbenzene and xylenes [20]. The main features of these are their reputation in being toxic and carcinogenic $[21,22]$. There are also some compounds stemming from the pollutants caused by traffic and photochemical processes; $\mathrm{NO}_{2}$ and $\mathrm{O}_{3}$ [23]. And it is clear that these kinds of pollutants have negative effects on the residents' health status and the surrounding area. One of these pollutants, known as $\mathrm{O}_{3}$ is available both on surface-level and troposphere. This pollutant is very hazardous to the human health which even can cause the death of premature babies, reduction in the amount of agricultural yields, alteration and shifts in ecosystems and devastation of infrastructure [23]. $\mathrm{SO}_{2}$ is one of the major urban air pollutants and it derives from fossil fuel combustion and smelting. If sulphuric acid is also manufactured in the surrounding area, it is highly probable that it is one of the pollutant source in the urban area. $\mathrm{SO}_{2}$ has an important effect on the human respiratory system and the environment due to its contribution to the acidification of soil and water in the ecosystem.

The objective of this research is to determine the atmospheric concentrations and spatial distribution of BTEX and inorganic air pollutants $\left(\mathrm{O}_{3}, \mathrm{NO}_{2}\right.$ and $\left.\mathrm{SO}_{2}\right)$ in the atmosphere of Yalova during the summer of 2015. In this research, a combination of passive sampling is used together with GIS-based geo-statistics and spatial autocorrelation statistics to characterise the spatial pattern of air quality based on the concentrations of these pollutants in Yalova.

\section{Materials and methods}

\section{Site description}

Yalova is a small city of about 127,670 inhabitants, located on the coast of the

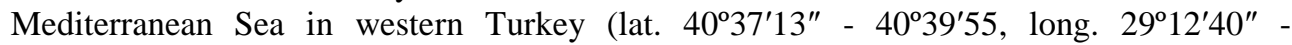
$29^{\circ} 18^{\prime} 50^{\prime \prime}$ E). Its north is surrounded by the Marmara Sea (Fig. 1). Yalova is situated on the northern side of Samanli Mountain and is built in a hilly terrain, which stretches perpendicularly to the sea. The most important economic activities in the city are industrial.

Yalova become a city on the $6^{\text {th }}$ June 1996 and is cited as being on the most important transportation route, which is a transit route between the metropoles of Istanbul, Bursa and Izmir and also one Organised Industrial Zone located near the city border. Yalova has a very active road which is used by many people both during the day and night. It lies in the western part of Turkey and the road is not remote from the centrum (see Fig. 1). These factors are very important for the quality of air in Yalova and also have a direct effect on it. 


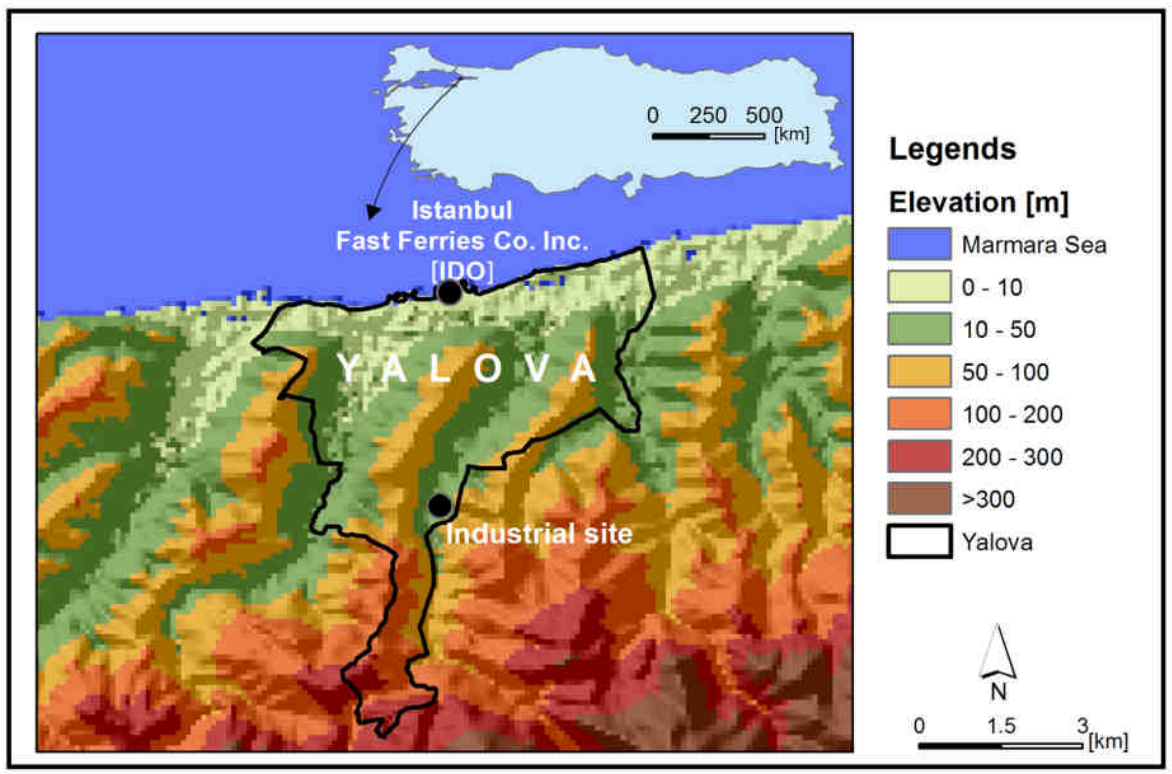

Fig. 1. Location of Yalova and surrounding topography

The direction of the wind and the emissions have an effect on the quality of air of Yalova. When we examine the wind directions in summer of 2015, we can see that the most frequent directions the wind is coming from the NE and NW on average. However, it is also brought about in the observations that wind coming from SW and SE is rare compared to the before mentioned directions (Fig. 2).
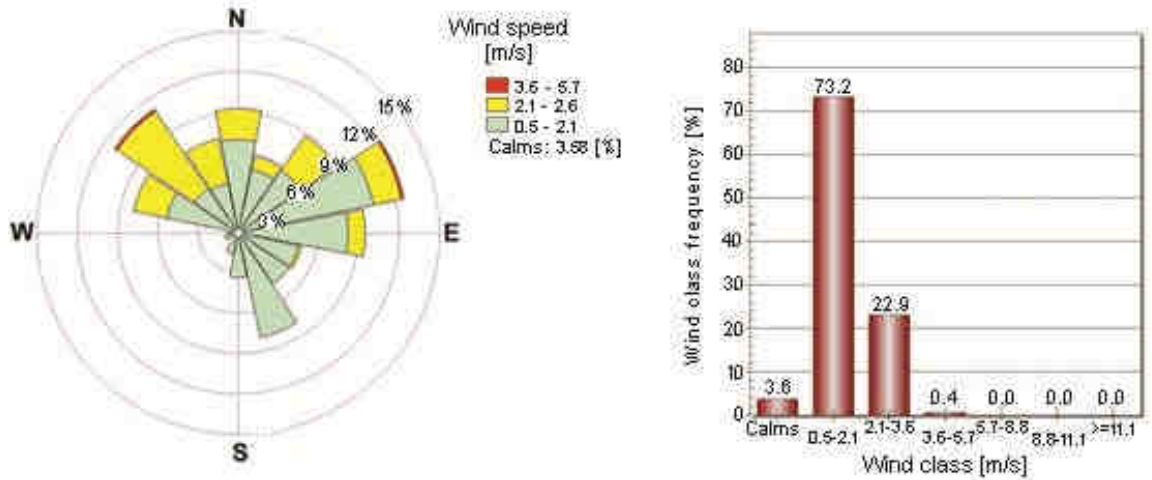

Fig. 2. Frequency distribution of wind directions (Turkey Weather Service) for summer 2015

\section{Data handling and analysis of passive samplers}

In this paper, we used $\mathrm{O}_{3}, \mathrm{NO}_{2}, \mathrm{SO}_{2}$ and BTEX (benzene, toluen, ethylbenzene, $\mathrm{o}$-xylene and $\mathrm{m}$,p-xylene) concentration data and land use data. When selecting the location 
of the monitoring stations, important consideration is given to different land uses in the city. The spatial variations of ambient air pollutants (BTEX, $\mathrm{O}_{3}, \mathrm{NO}_{2}$ and $\mathrm{SO}_{2}$ ) with five land-use types, residence, rural, highway, side road and industry area, were investigated at 40 stations in Yalova (Fig. 3). Measurements of $\mathrm{NO}_{2}, \mathrm{SO}_{2}, \mathrm{O}_{3}$ and BTEX concentrations were performed using passive diffusion samplers during 15-day intervals from the $7^{\text {th }}$ to the $26^{\text {th }}$ August 2015.

Stainless steel cylindrical tubes with a diameter of $5.8 \mathrm{~mm}$ were used for passive sampling of BTEX and acrylic rubber septa with a diameter of $11 \mathrm{~mm}$ were used for passive sampling of $\mathrm{SO}_{2}, \mathrm{NO}_{2}$ and $\mathrm{O}_{3}$. For the sampling of $\mathrm{SO}_{2}, \mathrm{O}_{3}$ and $\mathrm{NO}_{2}$ concentrations, diffusion tubes were used which were modified analyst type. The tubes were then set up in chosen areas in a vertical position 2-3.5 m above the ground, which roughly corresponds to the human breathing zone. Objects such as lights in the streets, trees and traffic lights were used for the fixation of the shelters with samplers. In the process of sampling the type of sheltered samplers were passive ones. The diffusion tubes were sent to licenced laboratories to be analysed using ion chromatographic techniques. In order to obtain a GIS geodatabase, the installation of diffusive samplers was supported by a Global Positioning System.

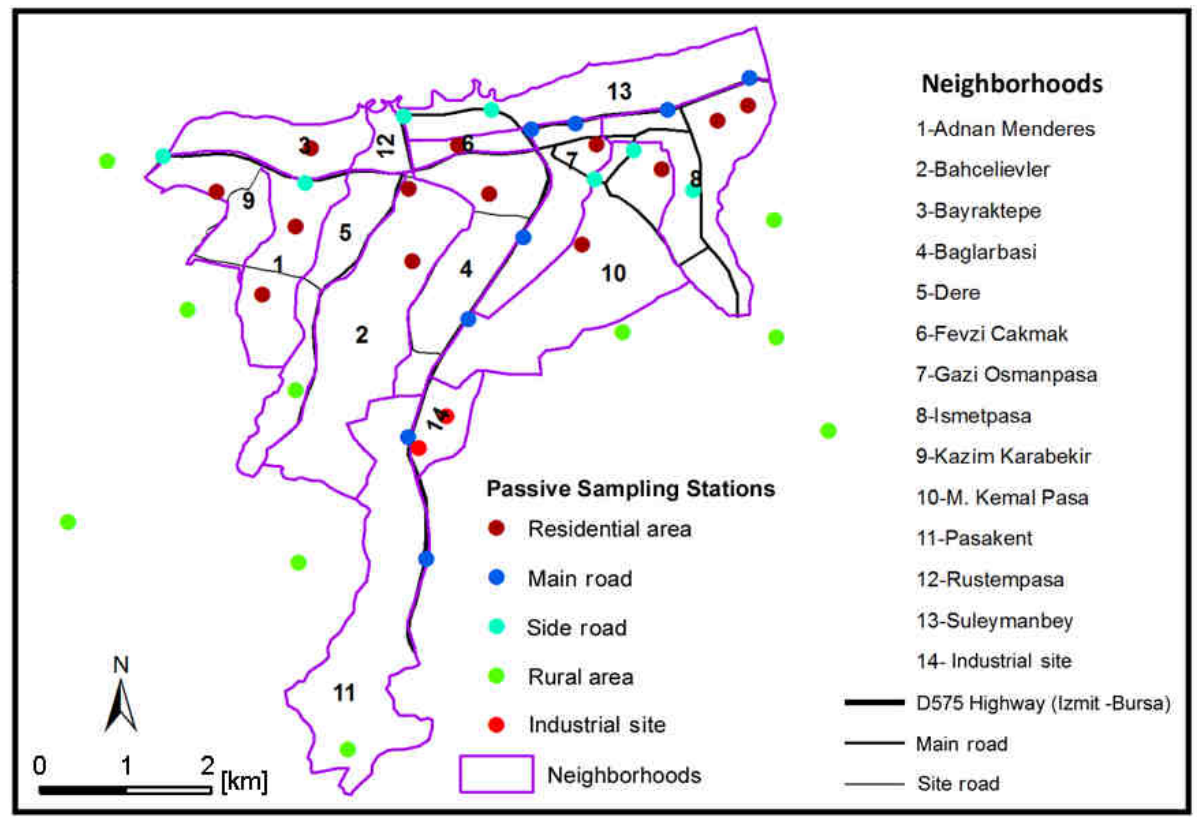

Fig. 3. Locations of surface air pollution $\left(\mathrm{O}_{3}, \mathrm{NO}_{2}, \mathrm{SO}_{2}\right.$, and $\left.\mathrm{BTEX}\right)$ monitoring stations in Yalova during 2015 summer

In this work, $\mathrm{SO}_{2}$ and $\mathrm{NO}_{2}$ passive samplers were prepared with $20 \%$ triethanolamine (TEA) aqueous solution and covered with Whatman GF/A filter papers. On the other hand, $\mathrm{O}_{3}$ samplers were impregnated with $1 \% \mathrm{NaNO}_{2}, 2 \% \mathrm{Na}_{2} \mathrm{CO}_{3}$ and glycerol aqueous solution. The air dried filter papers were fixed to the passive sampler base at $5 \mathrm{~mm}$ height. After exposure to definite time period, the tubes were collected and closed with caps. In this step, $\mathrm{SO}_{2}$ and $\mathrm{NO}_{2}$ samples were extracted with $10 \mathrm{~cm}^{3}$ of ultrapure water and $0.3 \mathrm{~cm}^{3}$ of $35 \%$ 
$\mathrm{H}_{2} \mathrm{O}_{2}$ solution, and the ozone samples were extracted with $5 \mathrm{~cm}^{3}$ of distilled water for 15 minutes. Analyzes of the extracted samples were carried out using ion-chromatography (IC) instrument. In IC analyzes, $\mathrm{NO}^{2-}, \mathrm{SO}_{4}{ }^{2-}$ and $\mathrm{NO}^{3-}$ ion concentrations were determined for $\mathrm{NO}_{2}, \mathrm{SO}_{2}$ and $\mathrm{O}_{3}$, respectively. The determined concentrations are multiplied by the excitation volumes and the amounts retained throughout the sampling period are calculated.

We used a cylindrical tube of $5.8 \mathrm{~mm}$ diameter made of stainless steel for the BTEX passive sampling. Sampler tubes were filled with a suitable adsorbent $(530 \pm 30 \mathrm{mg}$ activated carbon). Volatile organic compounds collected by adsorption in passive sampling tubes were analyzed by FID Gas Chromatography after separation with carbon bisulfide. Concentration calculations were made for each pollutant using Fick's law.

\section{Interpolation process and spatial clustering}

The meteorological and geographical conditions of a city, together with human activities, produce a characteristic air pollution pattern in each city. In the study, concentration maps were obtained using an IDW algorithm. According to Myers [15], while making predictions on values at unsampled areas, more remarks are assigned to closer locations than remote ones, that's why IDW is one popular form of interpolation [11, $12,24]$. Therefore in this study we use IDW. Furthermore, by design, IDW methods respect the range of the original observations (from the 40 monitoring stations), whereas the other methods, like kriging, do not.

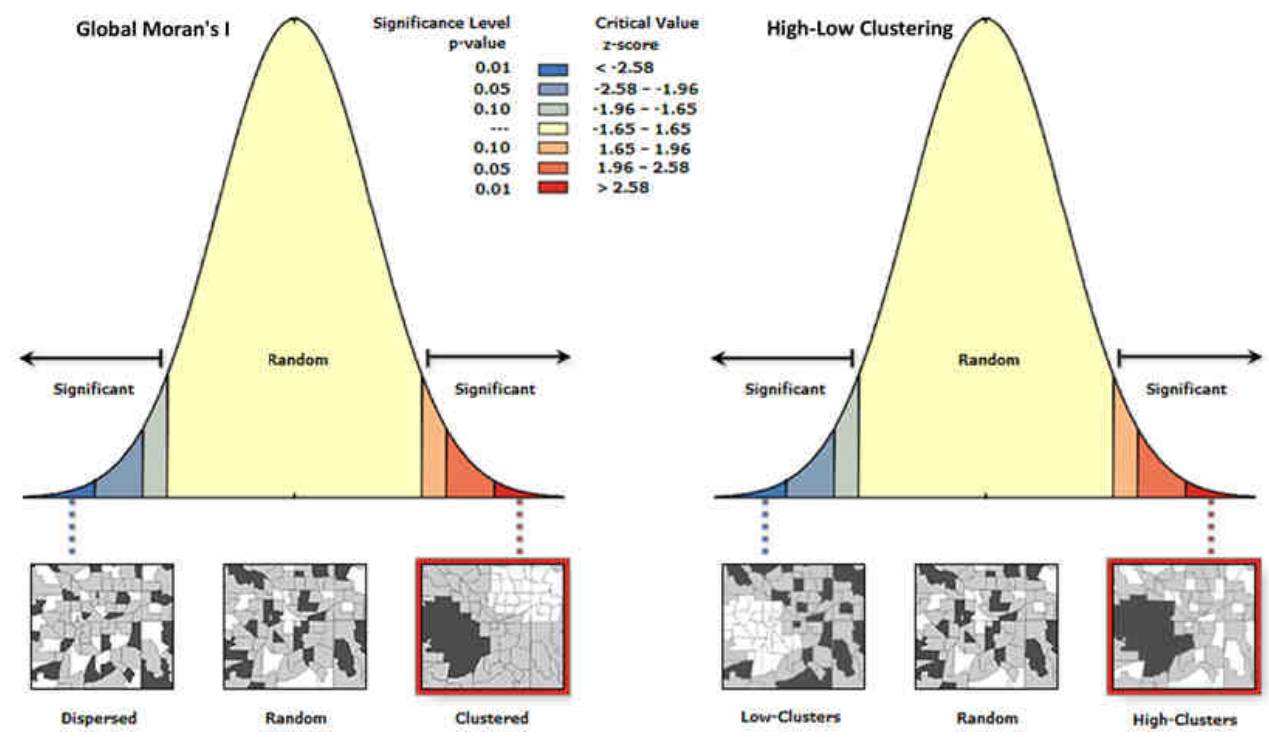

Fig. 4. Example graphs of output of the spatial autocorrelation tool applied to rotation angles

When we make a comparison between the statistical cluster analysis and the thematic maps of IDW, we see that cluster model is more objective for analysing spatial patterns because it provides us with information about the positions of spatial clusters, where they exist. The other information provided with that analysis are the types of spatial correlation [25]. In this study Global Moran's I and the Getis-Ord General G-statistic (Gi) were used to 
measure the spatial autocorrelation of pollutants. To measure the whole clustering The Global Moran's I [26] was in effect. But, in identifying hot-spots and cold-spots this measure is not effective because of the difference in types. So, the availability of these spots over the urban area were detected using the General Gi model. Detailed information about these statistical models could be obtained from Lee and Wong [19].

These global metrics give summary values for the whole research area. However, the magnitude of spatial autocorrelation of pollutants is not necessarily uniform over the urban area [25]. The importance of local statistics can be recognized in spatial autocorrelations; capturing the spatial heterogeneity and identifying the cluster points. In determining the high and low values attributed for the identification of spatial clusters, we used the Local Gi statistics developed by Getis and Ord [27]. If a local Gi is indicating high values, it points to hot-spots because of being higher than the mean value, however, if the value is lower than, it points to cold-spots.

In a cluster map the results of the analysis are shown. And for mapping each type of pollutant in the area, z-scores of both values were used. At the significant level of 0.05; the indication of statistical significance is measured by the z-scores being less than 1.96 or more than 1.96 (Fig. 4).

\section{Results and discussion}

\section{Spatial distribution pattern}

Descriptive statistics related to the BTEX concentrations assessed as the result of passive sampling are given in Table 1. Toluene is the pollutant with the highest concentration in the atmosphere of Yalova. The mean value of toluene was measured as $5.83 \mu \mathrm{g} / \mathrm{m}^{3}$ and the highest toluene concentration was measured as $43.64 \mu \mathrm{g} / \mathrm{m}^{3}$. The standard deviation of toluene was found to be high and this indicates that toluene concentrations are regionally quite unstable. It was found out that a change occurred in the mean values of toluene concentrations at a rate of approximately $135 \%$ in time and space. Xylene is the organic pollutant with the second highest concentration in the city atmosphere. The standard deviation of total xylene concentrations was also quite high and measured to be around $67 \%$.

Land use and land cover largely determine the type and amount of air pollutants. Land use variables were investigated to determine whether any of these were correlated with the concentration ratios in Yalova. Table 2 shows how assessed BTEX concentrations vary as a result of different land use type in the city. The majority of emitting facilities in Yalova are located in a distinct industrial core that is separate from residential areas. However, it is close to the residential areas. Concentrations of toluen, ethylbenzene, o-xylene and $\mathrm{m}, \mathrm{p}$-xylene are higher in the industrial core but it is determined that benzene is higher around the main road.

Traffic emissions can also be regarded as the sources of toluene-benzene (T/B) and xylene-ethylbenzene $(\mathrm{X} / \mathrm{E})$ depending on their ratio in the area. Some studies have revealed that the ratios of T/B are in the rise in relation to the volume of the traffic, emission ratios in the industry and also some other source causes in dense locations [28, 29]. As the organic compounds of gasoline, Benzene and toluene spread from the emissions of vehicles with engine to the atmosphere. Toluene content of the exhausts of motor vehicles depends on the type of the fuel and it is three- to four-times greater than that of benzene. In gasoline, toluene content is five-times greater. The T/B ratio is a characteristic that implies the 
emissions of vehicles [30]. Usually, when the T/B ratio is less than 5 in city atmospheres in the world, it is accepted that the main source of both toluene and benzene are traffic emissions [31]. A high ratio of T/B indicates that the impacts arising from industry and traffic are high in the area [29].

Descriptive statistics of BTEX concentrations $\left[\mu \mathrm{g} / \mathrm{m}^{3}\right]$

Table 1

\begin{tabular}{|c|c|c|c|c|c|c|c|}
\hline Descriptive statistics & $\mathbf{B}$ & $\mathbf{T}$ & $\mathbf{E}$ & $\mathbf{o - X}$ & $\mathbf{m , p}-\mathbf{X}$ & $\sum \mathbf{X}$ & Hourly-B \\
\hline Average & 1.46 & 5.8 & 1.15 & 1.38 & 2.1 & 3.3 & 5.0 \\
\hline Standard deviation & 0.43 & 7.9 & 0.49 & 0.59 & 1.7 & 2.2 & 1.5 \\
\hline Median & 1.40 & 3.5 & 1.05 & 1.24 & 1.8 & 3.0 & 4.8 \\
\hline Range & 1.46 & 42.1 & 2.45 & 3.16 & 8.3 & 12.1 & 5.0 \\
\hline Min. & 0.81 & 1.6 & 0.76 & 0.85 & 0.7 & 0.8 & 2.8 \\
\hline Max. & 2.27 & 43.6 & 3.21 & 4.01 & 9.0 & 13.0 & 7.7 \\
\hline
\end{tabular}

B: Benzene, T: Toluene, E: Ethylbenzene, X: Xylene

Mean BTEX concentrations in differnet landuse $\left[\mu \mathrm{g} / \mathrm{m}^{3}\right]$

Table 2

\begin{tabular}{|c|c|c|c|c|c|c|c|c|c|}
\hline $\begin{array}{c}\text { Urban } \\
\text { land use }\end{array}$ & $\mathbf{B}$ & $\mathbf{T}$ & $\mathbf{E}$ & $\mathbf{o - X}$ & $\mathbf{m , p}-\mathbf{X}$ & $\sum \mathbf{X}$ & Hourly-B & $\mathbf{T} / \mathbf{B}^{\mathbf{1}}$ & $\mathbf{X} / \mathbf{E}^{\mathbf{2}}$ \\
\hline Main road & 1.98 & 6.19 & 1.30 & 1.51 & 1.75 & 3.26 & 6.73 & 3.13 & 2.50 \\
\hline Side road & 1.53 & 4.36 & 1.13 & 1.38 & 2.15 & 3.53 & 5.22 & 2.85 & 3.12 \\
\hline Residential area & 1.33 & 4.14 & 1.03 & 1.23 & 1.96 & 3.19 & 4.53 & 3.11 & 3.09 \\
\hline Industrial site & 1.88 & 37.02 & 2.97 & 3.38 & 7.95 & 11.33 & 6.38 & 19.69 & 3.81 \\
\hline Rural area & 1.10 & 2.20 & 0.82 & 0.95 & 1.13 & 1.75 & 3.73 & 2.00 & 2.13 \\
\hline
\end{tabular}

B: Benzene, T: Toluene, E: Ethylbenzene, X: Xylene, ${ }^{1}$ Toluene/Benzene, ${ }^{2}$ Xylene /Ethylbenzene

When T/B values get close to 1 , then they can be regarded as the indicator of emissions related with traffic in urban areas. And regarding the location of the pollutant source, this ratio will be on the rise in relation to the distance getting closer [32]. The T/B values in Yalova are much more higher than 1 which can be interpreted as the existence of another source of toluene. According to Liu et al. [33], some processes like cleaning and printing may create evaporations of solvent and this could be taken into consideration for the source of toluene as T/B ratio was determined to be as high as (> 19.7) in industrial areas.

Some researchers also use the $\mathrm{X} / \mathrm{E}$ ratio to understand the characteristics of pollutant VOCs [34, 35]. Meta-para xylene and ethylbenzene undergo different reactions with hydroxyl radicals in the atmosphere and the reaction of these two compounds determines their duration in the atmosphere. As m,p-xylene is more reactive than ethylbenzene, this ratio decreases as the duration of VOCs in the atmosphere increases. In ambient VOC investigation, the $\Sigma \mathrm{X} / \mathrm{E}$ ratio is also used by many researchers to evaluate the relative age of the air parcels [29, 34, 35]. In general, there is an opposition between xylene and ethylbenzene regarding the reactivity species; while the former is regarded highly reactive, the latter is regarded to be low in reactivity. Therefore, low $\mathrm{X} / \mathrm{E}$ ratios presents an air parcel which is aged and indicates an area less affected by fresh emissions. Atmospheric life spans of m,p-xylene and ethylbenzene are 3 and 8 hours, respectively and the $\mathrm{X} / \mathrm{E}$ ratio will decrease as $\mathrm{m}, \mathrm{p}$-xylene will move away from the pollutant source as they react faster than ethylbenzene [36]. The X/E ratio is high in industrial areas and residential areas where traffic is intense; however, this ratio is found to be relatively low in rural areas. This situation gives rise to the idea that photochemical reactions are more effective because of 
existing fresh emissions in the areas where the industry and traffic is dense. Also, this suggests that BTEX in these areas may also come from non-traffic sources. Unleaded gasoline \#92, unleaded gasoline \#95, unleaded gasoline \#98 and diesel are commonly used in Yalova. Therefore, another reason for the high ratios in traffic-heavy areas of the city is associated with the fact that such emissions and ratios depend greatly on the gasoline used in different investigated countries. According to Truc and Oanh [35] for different samples in urban areas a wide range of ratios are reported. To provide examples to these reports; in Tokyo 1.3 and in Athens 4.8 be the most common ones range from 2.0 to 3.0 [34]. It is known that low $\mathrm{X} / \mathrm{E}$ values are connected with active photochemical reactions $[37,38]$.

Statistical measures related to inorganic pollutant concentrations $\left(\mathrm{O}_{3}, \mathrm{NO}_{2}\right.$ and $\left.\mathrm{SO}_{2}\right)$ are given in Tables 3 and 4. Ozone mass concentrations range between 51.27 and $103.95 \mu \mathrm{g} / \mathrm{m}^{3}$. In the summer, $\mathrm{O}_{3}$ concentrations in rural areas are higher than those in the city centre. During the study period, mean $\mathrm{O}_{3}$ concentrations are over $60 \mu \mathrm{g} / \mathrm{m}^{3}$, which is the limit value given by the European Union Framework Directive on Air Quality Assessment and Management [39]. Nitrogen dioxide concentrations range from 12.65 to $80.73 \mu \mathrm{g} / \mathrm{m}^{3}$ during the summer period and the mean concentration is $35.64 \mu \mathrm{g} / \mathrm{m}^{3}$. This mean value is over the European Union limit value $\left(40 \mu \mathrm{g} / \mathrm{m}^{3}\right)$ around main roads. $\mathrm{SO}_{2}$ concentrations range from 3.14 to $4.58 \mu \mathrm{g} / \mathrm{m}^{3}$ during the summer period and the mean concentration is $3.95 \mu \mathrm{g} / \mathrm{m}^{3}$.

Descriptive statistics of inorganic pollutants $\left[\mu \mathrm{g} / \mathrm{m}^{3}\right]$

Table 3

\begin{tabular}{|c|c|c|c|}
\hline Descriptive statistics & $\mathbf{N O}_{\mathbf{2}}$ & $\mathbf{O}_{\mathbf{3}}$ & $\mathbf{S O}_{\mathbf{2}}$ \\
\hline Average & 36 & 84 & 3.9 \\
\hline Standard deviation & 27 & 28 & 1.7 \\
\hline Median & 25 & 86 & 3.8 \\
\hline Range & 98 & 121 & 9.0 \\
\hline Min. & 8 & 12 & 2.2 \\
\hline Max. & 106 & 133 & 11.2 \\
\hline
\end{tabular}

Regional variation of inorganic pollutants $\left[\mu \mathrm{g} / \mathrm{m}^{3}\right]$

\begin{tabular}{|c|c|c|c|}
\hline Urban land use & $\mathbf{N O}_{\mathbf{2}}$ & $\mathbf{O}_{\mathbf{3}}$ & $\mathbf{S O}_{\mathbf{2}}$ \\
\hline Main road & 80.73 & 51.27 & 4.58 \\
\hline Side road & 39.35 & 78.04 & 3.41 \\
\hline Residential area & 24.88 & 103.95 & 3.95 \\
\hline Industrial site & 32.78 & 73.36 & 3.14 \\
\hline Rural area & 12.65 & 88.62 & 4.04 \\
\hline
\end{tabular}

For forming a continuous surface, interpolation was used as a means of making evaluations by the observed values between the points over a space. For indicating the spatial patterns of the variables $\left(\mathrm{O}_{3}, \mathrm{NO}_{2}, \mathrm{SO}_{2}\right.$ and BTEX) IDW was implemented. The map of BTEX concentrations at an individual basis estimated in summer time in the city of Yalova are presented in Figure 5. Concentrations of emissions were observed to be very different in urban and rural locations. Maximum average concentration of BTEX was found along the main road while minimum at less residential areas, because high levels of BTEX could be attributed to very high traffic density and slow traffic. The concentration of BTEX was observed to be lower in distance to the sources such as the main traffic route. The level 
of benzene pollution is observed to be high, especially in neighbourhoods along the D575 highway and in the city centre where dense building constructions and trade zones are present (Fig. 5). Benzene concentrations reach maximum levels in city centres where there is dense traffic. The neighbourhoods with the highest levels of benzene pollution are Dere, Gazi Osmanpasa, Suleymanbey and Sanayi. The west side of the city and the areas with relatively less traffic and settlement have comparatively lower benzene concentrations.

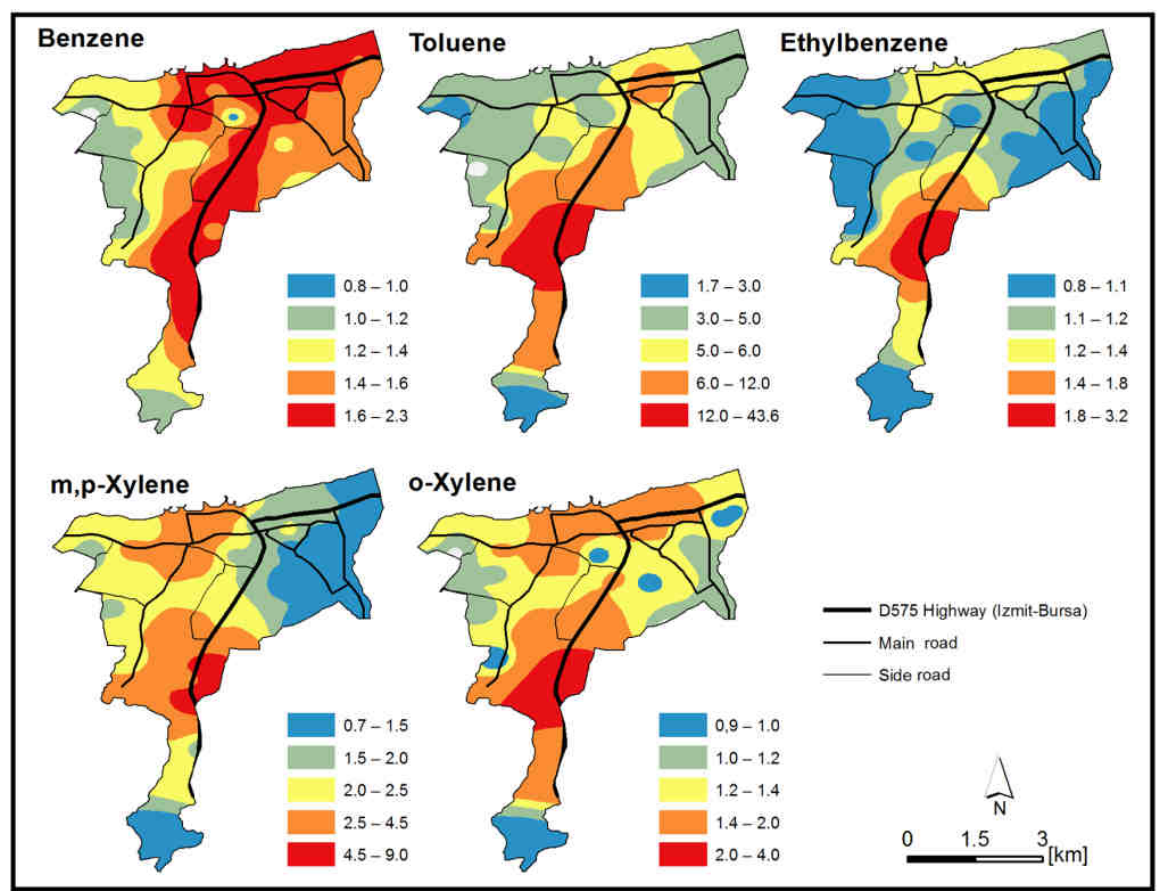

Fig. 5. Maps showing values of benzene, toluene, ethylbenzene $\mathrm{m}, \mathrm{p}-\mathrm{xylene}$ and $\mathrm{o}-\mathrm{xylene}\left[\mu \mathrm{g} / \mathrm{m}^{3}\right]$

Toluene has shown higher effects especially in the industrial zone along the D575 highway and the neighbourhoods surrounding the industrial area (Fig. 5). In the industrial zone there are car mechanic shops, paint and polish shops and auto repair shops, where a wide range of repairs are conducted. The parts of the neighbourhoods of Bahcelievler, Gazi Osman Pasa, Pasakent and Baglarbasi that are close to the industrial zone display a remarkably high level of toluene. It is observed that the places with a high toluene concentration are expanding towards the city centre in the direction of the Bursa-Istanbul highway. Toluene concentrations, which are over $12.0 \mu \mathrm{g} / \mathrm{m}^{3}$ in the industrial zone, range from 6.0 to $12.0 \mu \mathrm{g} / \mathrm{m}^{3}$ in the surrounding neighbourhoods. The cleanest areas of the city, with regards to toluene pollution, are the residential areas in the east and west ends.

Like toluene, ethylbenzene also displays highest levels in the industrial zone (Fig. 5). The impact of ethylbenzene pollution decreases with distance from the industrial zone but not in the parts of the surrounding neighbourhoods close to the industrial area. The neighbourhoods most polluted and affected by ethylbenzene pollution stemming from the industrial zone are Gazi Osman Pasa, Pasakent, Fevzi Cakmak, Suleymanbey and 
Baglarbasi. Another area with a significantly high ethylbenzene concentration is the area where Istanbul Fast Ferries Co. Inc. (IDO) is present (Fig. 1). The cleanest areas of the city, with regards to ethylbenzene, are the residential areas in the east and west sides of the city.

The areas with the highest values of $\mathrm{m}, \mathrm{p}$-xylenes and o-xylene pollution are the industrial zone and its close surrounding (Fig. 5). The levels of both pollutants decrease with distance from the industrial zone. The impacts of both pollutants can also be observed in areas close to the industrial zone, which is a source area for the pollutants, in the surrounding neighbourhoods. These neighbourhoods are Baglarbasi, Bayraktepe, Mustafekemalpasa and Pasakent. Another remarkable area for both pollutants is the neighbourhood close to IDO in the north side of the city. This side of the city displays the highest traffic density. Fevzi Cakmak and Rustempasa neighbourhoods have remarkably high values of m,p-xylene concentrations. In these neighbourhoods, the values of m,p-xylene and o-xylene concentrations range from 2.5 to $4.5 \mu \mathrm{g} / \mathrm{m}^{3}$ and 1.4 to $2.4 \mu \mathrm{g} / \mathrm{m}^{3}$, respectively. The cleanest areas of the city, with regards to $\mathrm{m}, \mathrm{p}$-xylene pollution, are the residential areas that are distant from the city centre on the east side of the city.

A map of $\mathrm{O}_{3}, \mathrm{NO}_{2}$ and $\mathrm{SO}_{2}$ concentrations for the summer period in Yalova are presented in Figure 6. The level of $\mathrm{NO}_{2}$ pollution is high, especially in neighbourhoods that expand along the Bursa-Istanbul highway and in the city centre where dense urban construction and trade zones are present (Fig. 6). The most polluted neighbourhoods, with regards to $\mathrm{NO}_{2}$ levels, are the parts surrounding the roads along this route. $\mathrm{NO}_{2}$ concentrations are an explicit indicator of traffic emissions. The area surrounding the IDO is also remarkable for the level of $\mathrm{NO}_{2}$ pollution. An important proportion of measured $\mathrm{NO}_{2}$ concentrations are formed by the oxidation of traffic-originated nitrogen monoxide (NO) in the atmosphere. Though, some proportion of $\mathrm{NO}_{2}$ can be released to the atmosphere directly as vehicle emissions $[40,41] . \mathrm{NO}_{2}$ concentrations in areas around the main road where the traffic is dense in the city are measured to be 6.3-times higher than in the rural area. It is understood that there is a negative correlation between $\mathrm{NO}_{2}$ and ozone concentrations measured in different parts of the city.

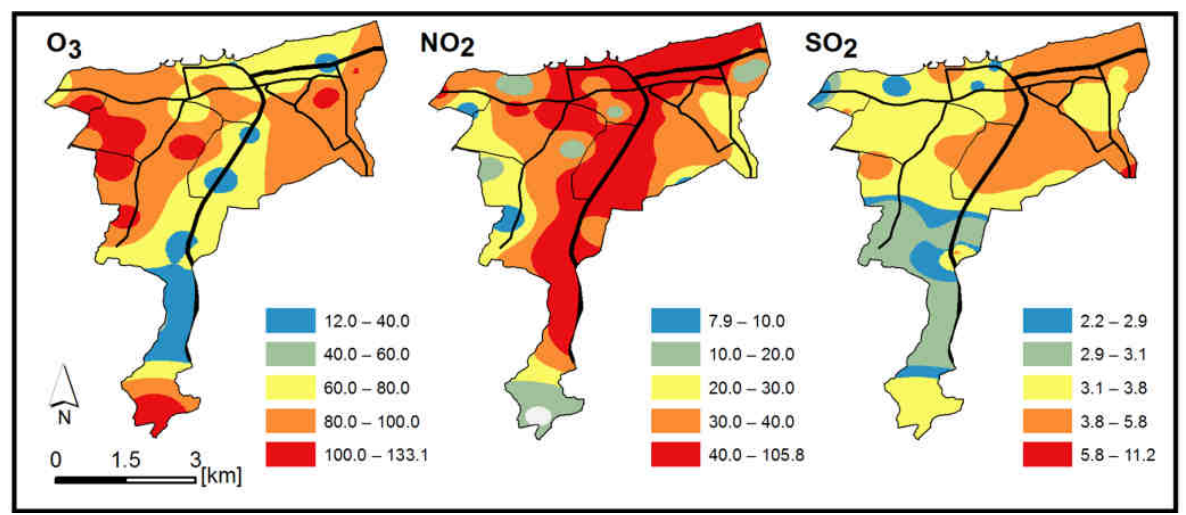

Fig. 6. Maps showing values of $\mathrm{O}_{3}, \mathrm{NO}_{2}$ and $\mathrm{SO}_{2}\left[\mu \mathrm{g} / \mathrm{m}^{3}\right]$

A reverse relation is inevitable between these two pollutants as the $\mathrm{NO}_{2}$ stemming from vehicles reacts with the ozone in the atmosphere, thus consuming the ozone and 
eventually causing the generation of $\mathrm{NO}_{2}$. In these areas, $\mathrm{NO}_{2}$ concentrations are over $40 \mu \mathrm{g} / \mathrm{m}^{3}$. The rate of concentration decreases east and west of road. These values do not exceed the value of $40 \mu \mathrm{g} / \mathrm{m}^{3}$, which is the limit required for the preservation of the current status of human health according to HKDYY (Regulations for the Assessment and Management of Air Quality). The surrounding areas, which exceed $30 \mu \mathrm{g} / \mathrm{m}^{3}$, are also important for protecting the vegetation. The most unpolluted areas of the city, with regards to $\mathrm{NO}_{2}$ pollution, is the Ismetpasa neighbourhood in the east, the Adnan Menderes neighbourhood in the west, the Pasakent neighbourhood on the south side of the city and parts of Kazim Karabekir neighbourhood, which are distant from the city centre.

The level of $\mathrm{O}_{3}$ increases radially from city centre (Fig. 6). In these areas $\mathrm{O}_{3}$ concentrations are over $100 \mu \mathrm{g} / \mathrm{m}^{3}$. The areas with the lowest values are the industrial zone and Bursa-Istanbul road. In summer, the annual mean value of $\mathrm{O}_{3}$ concentrations is over the $60 \mu \mathrm{g} / \mathrm{m}^{3}$ limit value of European Union Framework Directive on Air Quality Assessment and Management [40]. $\mathrm{O}_{3}$ concentrations are at its highest rate in rural areas; lower in areas close to the city and even lower in dense traffic areas unlike other pollutants. The $\mathrm{NO}_{2}$ and BTEX concentrations in areas with dense traffic repress the generation of $\mathrm{O}_{3}$ and cause the photochemical exhaustion of ozone. As a result of this, $\mathrm{O}_{3}$ concentrations in these areas are low. As $\mathrm{NO}_{2}$ and $\mathrm{O}_{3}$ react with each other in photochemical processes in the atmosphere, usually $\mathrm{O}_{3}$ levels increase in areas where $\mathrm{NO}_{2}$ levels decrease. Spatial $\mathrm{NO}_{2}$ concentrations are measured to be higher in urban locations whereas lower in rural locations. This is related to the low levels of $\mathrm{O}_{3}$ in the city atmosphere. Areas where the ozone values are high are places to which the pollutant sources, such as traffic and industry that can cause the exhaustion of ozone by reacting with ozone, are distant. Ozone has a longer duration in rural atmospheres where ozone is not exhausted by chemical reactions. From studies carried out on this subject, it is known that pollutants move to rural areas from the city centres and industrial zones according to various factors of meteorology and air movements and generate ozone by photochemical reactions in these areas [42].

Figure 6 shows the spatial distribution of $\mathrm{SO}_{2}$. It is observed that $\mathrm{SO}_{2}$ levels are quite low and never exceed the limit values. The areas where $\mathrm{SO}_{2}$ is at its highest are the neighbourhoods on the northeast side of the city. Industrial zones also give rise to high pollutant concentrations in the south side of the city. $\mathrm{SO}_{2}$ concentrations are low, as expected in the summer period. $\mathrm{SO}_{2}$ in city atmospheres is usually caused by the use of coal for domestic heating in the winter season. As heating not required during the summer period, $\mathrm{SO}_{2}$ concentrations are low. However, industry and diesel vehicles can also be sources of $\mathrm{SO}_{2}$ release to the atmosphere. Although, when the $\mathrm{SO}_{2}$ pollution map in Figure 5 is analysed, it is revealed that the east-west regression trend of air quality is affected by pollutant sources that are located outside of the city, on the east side. If the northeast direction of the wind is also taken into consideration, it can be said that pollutant sources from this area affect the city of Yalova (Fig. 2).

\section{Spatial-cluster and spatial-outlier analyses}

In Table 5 and Figure 7, the outcomes of global Moran's statistics and Getis-Ord G analysis are presented. A positive autocorrelation in the area is a sign showing that similar values have more probability of being close to each other.

In other words, tendency is measured by the tests of autocorrelation, through all data locations. In these tests correlation means a lot; for lower or higher values correlating more closely with each other in spatial areas with other values; high or low. In Table 5, 
significant $p$ values are listed with positive values of Moran's I (i.e. $p<0.01$ ) for $\mathrm{SO}_{2}, \mathrm{O}_{3}$, $\mathrm{NO}_{2}$ and BTEX. These outcomes are reflections of the dependency of high values; they depend on the values in the locations next to them (i.e., higher values will cluster in space with other high values).

Spatial Autocorelation of $\mathrm{O}_{3}, \mathrm{NO}_{2}, \mathrm{SO}_{2}$ and BTEX in Yalova

Table 5

\begin{tabular}{|c|c|c|c|c|c|c|}
\hline Pollutans & \multicolumn{3}{|c|}{ High/low clustering } & \multicolumn{3}{|c|}{ Global Moran's I } \\
\hline $\mathrm{O}_{3}$ & $\begin{array}{c}\text { Observed General G: } \\
\text { z-score: } \\
\text { p-value: }\end{array}$ & $\begin{array}{c}0.000 \\
-0.650 \\
0.516 \\
\end{array}$ & $\square$ & $\begin{array}{c}\text { Moran's Index: } \\
\text { z-score: } \\
\text { p-value: }\end{array}$ & $\begin{array}{c}-0.020 \\
0.085 \\
0.933\end{array}$ & $\square$ \\
\hline $\mathrm{NO}_{2}$ & $\begin{array}{c}\text { Observed General G: } \\
\text { z-score: } \\
\text { p-value: }\end{array}$ & $\begin{array}{l}0.000 \\
3.506 \\
0.000\end{array}$ & & $\begin{array}{l}\text { Moran's Index: } \\
\text { z-score: } \\
\text { p-value: }\end{array}$ & $\begin{array}{l}0.091 \\
2.447 \\
0.014\end{array}$ & \\
\hline $\mathrm{SO}_{2}$ & $\begin{array}{c}\text { Observed General G: } \\
\text { Z-score: } \\
\text { p-value: }\end{array}$ & $\begin{array}{c}0.000 \\
-0.014 \\
0.989\end{array}$ & 담 & $\begin{array}{l}\text { Moran's Index: } \\
\text { z-score: } \\
\text { p-value: }\end{array}$ & $\begin{array}{l}0.035 \\
1.364 \\
0.172\end{array}$ & ] \\
\hline Benzene & $\begin{array}{c}\text { Observed General G: } \\
\text { z-score: } \\
\text { p-value: }\end{array}$ & $\begin{array}{l}0.000 \\
4.035 \\
0.001\end{array}$ & & $\begin{array}{l}\text { Moran's Index: } \\
\text { z-score: } \\
\text { p-value: }\end{array}$ & $\begin{array}{l}0.213 \\
4.980 \\
0.000\end{array}$ & \\
\hline Toluene & $\begin{array}{c}\text { Observed General G: } \\
\text { z-score: } \\
\text { p-value: }\end{array}$ & $\begin{array}{l}0.001 \\
2.689 \\
0.007\end{array}$ & & $\begin{array}{l}\text { Moran's Index: } \\
\text { z-score: } \\
\text { p-value: }\end{array}$ & $\begin{array}{l}0.146 \\
4.446 \\
0.000\end{array}$ & \\
\hline Ethylbenzene & $\begin{array}{c}\text { Observed General G: } \\
\text { z-score: } \\
\text { p-value: } \\
\end{array}$ & $\begin{array}{l}0.000 \\
2.334 \\
0.019 \\
\end{array}$ & & $\begin{array}{l}\text { Moran's Index: } \\
\text { z-score: } \\
\text { p-value: }\end{array}$ & $\begin{array}{l}0.116 \\
4.492 \\
0.000\end{array}$ & \\
\hline m,p-xylene & $\begin{array}{c}\text { Observed General G: } \\
\text { z-score: } \\
\text { p-value: }\end{array}$ & $\begin{array}{l}0.000 \\
2.074 \\
0.038 \\
\end{array}$ & & $\begin{array}{l}\text { Moran's Index: } \\
\text { Z-score: } \\
\text { p-value: } \\
\end{array}$ & $\begin{array}{l}0.164 \\
4.379 \\
0.000 \\
\end{array}$ & \\
\hline o-xylene & $\begin{array}{c}\text { Observed General G: } \\
\text { z-score: } \\
\text { p-value: }\end{array}$ & $\begin{array}{l}0.000 \\
3.318 \\
0.001\end{array}$ & & $\begin{array}{l}\text { Moran's Index: } \\
\text { z-score: } \\
\text { p-value: }\end{array}$ & $\begin{array}{l}0.112 \\
3.075 \\
0.002\end{array}$ & \\
\hline
\end{tabular}

Contrary to the indications of strong global spatial autocorrelation, clusters of pollutants displayed non-stationary, as indicated in Figure 7. By using the Gi statistics the hot spots are evaluated for the measurement of values which cluster in a sub region of the research location. We also used this statistical method to determine the locations of the spatial clusters of high or low values. And the reflection of the features in sets of data, is a z-score. For statistically significant positive z-scores; when the z-score is larger, the clustering of high values will be more intense as well (hot-spot). And as for negative scores, the smaller this time will reflect the more intense clustering of low values (cold-spot).

We found that significant air pollutants, except $\mathrm{O}_{3}$ and $\mathrm{SO}_{2}$, cluster in Yalova. Although the $\mathrm{NO}_{2}$ and BTEX had remarkable spatial positive correlation, more than half of the samples of these pollutants displayed no significant spatial pattern in the area.

For $\mathrm{NO}_{2}$, significant hot-spots on the highway are remarkable (Fig. 7). $\mathrm{O}_{3}$ was observed in areas of low urbanisation had were high-high clustered. Keuken et al. [43] also reported that in Europe busy streets and city locations have low level of ozone concentrations. One focus point they made was that; the depletion of ozone reacts with emitted nitric oxide and this process is tending to be more important than the re-creation of ozone. The reduced nitrogen oxide emissions caused by the traffic can actually cause ozone levels to increase in city centres due to traffic restrictions. In this situation, the nitric oxide 
formerly acts as a local ozone scavenger [44]. Among BTEX, toluene, ethylbenzene, m,p-xylene and o-xylene displayed significant hot-spots at industrial sites in which many small industries exist. However, benzene also displayed hot-spots on the main roads and intersections where traffic is dense and in industrial area. This shows that benzene is affected by traffic and industrial activities. Like benzene, $\mathrm{NO}_{2}$ displayed hot-spots along the main roads and intersections where traffic is dense, especially along the Istanbul-Izmir highway. The traffic line in the centre of the city is the reason for the high-high cluster. We could not determine any hot-spots for $\mathrm{SO}_{2}$ in Yalova in summer. However, in the western side of the city where there is a lower population, cold-spots for $\mathrm{SO}_{2}$ can be found.

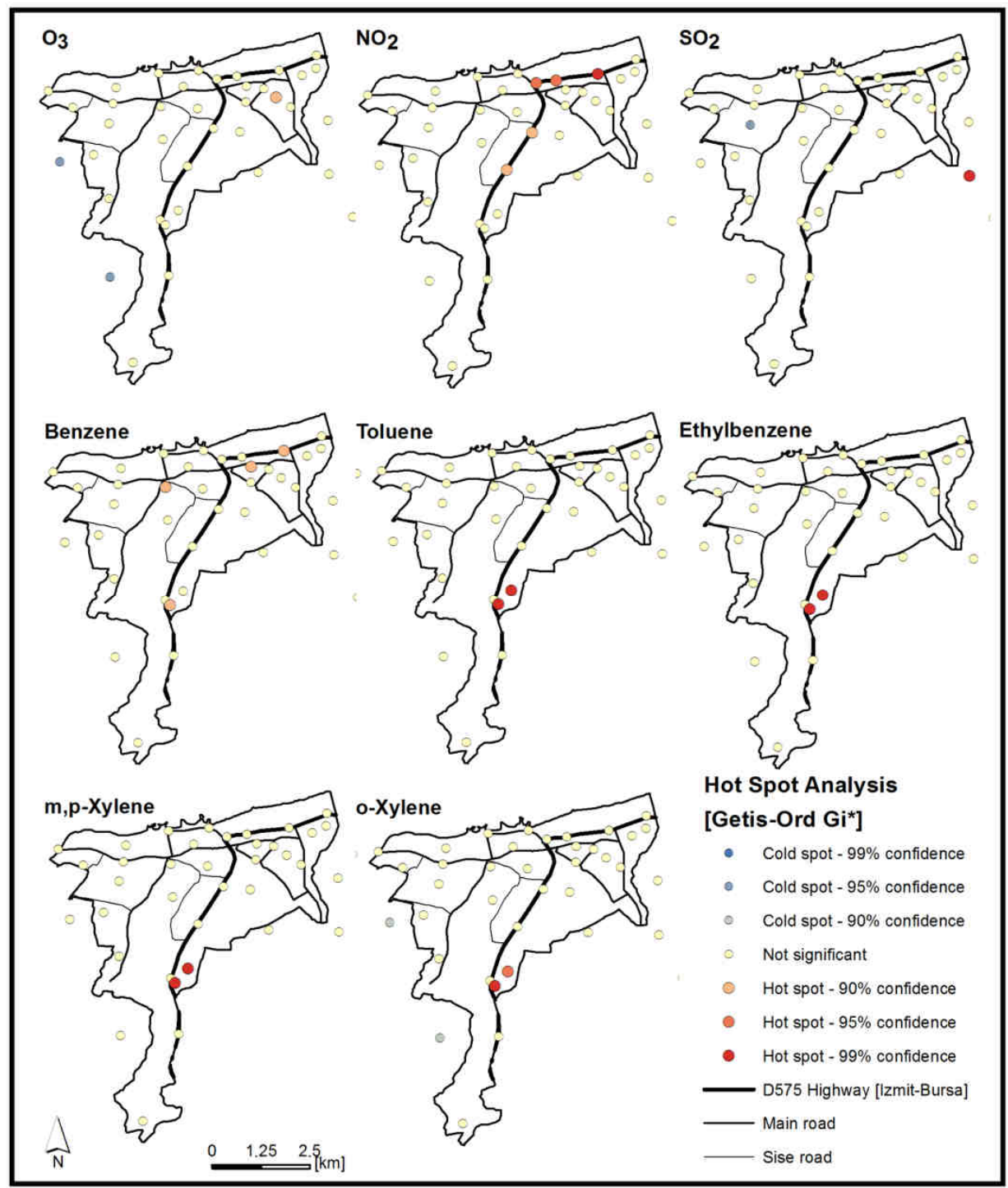

Fig. 7. Maps showing hot-spots of $\mathrm{O}_{3}, \mathrm{NO}_{2}, \mathrm{SO}_{2}$ and BTEX 


\section{Conclusions}

A study of the BTEX and inorganic pollutant concentrations in ambient air of Yalova city was implemented to find out the composition and concentration distribution of these pollutants in regards to the type of landuse: residence, rural, highway, side road and industry. The GIS-based mapping applied in this research appears to offer an effective method for mapping anthropogenic-related pollutants. The maps developed steadily provide well predictions of levels of pollutants at unsampled locations. In smaller field researches, in which observed data is uncommon and yet the necessity for high resolution maps is crucial and GIS interpolation techniques offers a powerful interpolation and analysis tool. This research puts forth the prospects for getting over the hindrance of infrequent spatial observations within the context of air pollution mapping. The availability of suitable mapping techniques is reduced to a great extent by small number of air quality monitors. We recommend the use of passive samplers, as these provide the most complete and detailed analysis of air quality. Also, our analysis has made it clear that spatial autocorrelation has a significant effect on the estimations of pollutant spatial clustering.

In the city Yalova, BTEX and $\mathrm{NO}_{2}$ concentrations were found to be higher along the highway passing through the centre of the city. Amongst the BTEX species, high concentrations of aromatic species, such as toluene, ethylbenzene and xylene were seen in areas where the industrial activity is common. In the course of this research, low concentrations of BTEX and $\mathrm{NO}_{2}$ were seen in areas with residential population. According to the findings of this study it was certain that besides the emissions caused by the traffic, industrial activity was also an important factor increasing the concentration levels of pollutants in the surrounding air. Also, the east of the city, which is densely populated, is found to be more polluted than the west of the city. Analysis demonstrated that there are high-high clusters around industrial areas and the highway, for all pollutants except $\mathrm{SO}_{2}$ and $\mathrm{O}_{3}$. In Yalova, large variability was observed in the $\mathrm{T} / \mathrm{B}$ ratios, indicating large contributions of these two compounds from point sources. Also, the mean T/B ratio was found to be higher and outside the range normally indicative of traffic. We have shown how a real analysis can improve the estimation of air quality. In light of this, the results have important implications for public policymaking.

\section{Acknowledgements}

The authors acknowledge the following contributions to this work: Merve Elibol, Dilek Unsal for data collection processing and South Marmara Development Agency for financial support. We also appreciate the assistance and help of the local authorities in the research area for their support in this study.

\section{References}

[1] Briggs DJ, Collins S, Elliott P, Fischer P, Kingham S, Lebret E. Mapping urban air pollution using GIS: a regression based approach. Int J Geogr Inf Sci. 1997;11:699-718. DOI: 10.1080/136588197242158.

[2] Cooper O, Parrish D, Stohl A, Trainer M, Nédélec P, Thouret V, et al. Increasing springtime ozone mixing ratios in the free troposphere over western North America. Nature. 2010;463:344-348. DOI: 10.1038/nature08708.

[3] Gilge S, Plass-Duelmer C, Fricke W, Kaiser A, Ries L, Buchmann B, et al. Ozone, carbon monoxide and nitrogen oxides time series at four alpine GAW mountain stations in central Europe. Atmos Chem Phys. 2010;10:12295-12316. DOI: 10.5194/acp-10-12295-2010. 
[4] Tecer LH, Tagil S. Impact of urbanization on local air quality: differences in urban and rural areas of Balikesir, Turkey. Clean. 2014;42(11):1489-1499. DOI: 10.1002/clen.201200640.

[5] Directive 2008/50/EC of the European Parliament and of the Council of 21 May 208 on ambient air quality and cleaner air for Europe. http://eur-lex.europa.eu/LexUriServ/LexUriServ.do?uri=OJ:L:2008:152:0001: 0044:EN:PDF.

[6] World Health Organization (WHO) Burden of disease from Ambient Air Pollution for 2012. Description of method Version 1.3. Geneva: World Health Organization; 2014, http://www.who.int/ phe/health_topics/outdoorair/databases/HAP_BoD_results_March2014.pdf.

[7] Vardoulakis S, Gonzales-Flesca N, Fisher BEA, Pericleous K. Spatial variability of air pollution in the vicinity of a permanent monitoring station in central Paris. Atmos Environ. 2005;39(15):2725-2736. DOI: 10.1016/j.atmosenv.2004.05.067.

[8] Wheeler A, Smith-Dorion M, Xu X, Gilbert N, Brook J. Intro-urban variability of air pollution in Windsor, Ontario-measurement and modelling for human exposure. Assess Environ Res. 2008;106:7-16. DOI: 10.1016/j.envres.2007.09.004.

[9] Olszowski T. Seasonal values of the gaseous concentrations of air quality ratings in a rural area. Ecol Chem Eng S. 2013;20(4):719-732. DOI: 10.2478/eces-2013-0050.

[10] Olszowski T, Kłos A. The impact of candle burning during All Saints' Day ceremonies on ambient alkyl-substituted benzene concentrations. Bull Environ Contam Toxicol. 2013;91:588-594. DOI: 10.1007/s00128-013-1104-6.

[11] Li L, Losser T, Yorke C, Piltner R. Fast inverse distance weighting-based spatiotemporal interpolation: A web-based application of interpolating daily fine particulate matter PM2.5 in the Contiguous U.S. using parallel programming and k-d tree. Int J Environ Res Public Health. 2014;11:9101-9141. DOI: 10.3390/ijerph110909101.

[12] Phillips DL, Tingey DT, Lee EH, Herstrom AA, Hogsett WE. Use of auxiliary data for spatial interpolation of ozone exposure in southeastern forests. Environmetrics. 1997;8(1):43-61. DOI: 10.1002/(SICI)1099-095X(199701)8:1<43::AID-ENV237>3.0.CO;2-G.

[13] Feng L, Ye B, Feng H, Ren F, Huang S, Zhang X, et al. Spatiotemporal changes in fine particulate matter pollution and the associated mortality burden in China between 2015 and 2016. Int J Environ Res Public Health. 2017;14:1321. DOI: 10.3390/ijerph14111321.

[14] Kethireddy SR, Tchounwou PB, Ahmad HA, Yerramilli A, Young JH. Geospatial interpolation and mapping of tropospheric ozone pollution using geostatistics. Int J Environ Res Public Health. 2014;11:983-1000. DOI: 10.3390/ijerph110100983.

[15] Myers DE. Interpolation and estimation with spatially located data. Chemometr Intell Lab. 1991;11:209-228. DOI: 10.1016/0169-7439(91)85001-6.

[16] Ikechukwu MN, Ebinne E, Idorenyin U, Raphael NI. Accuracy assessment and comparative analysis of IDW, spline and kriging in spatial interpolation of landform (Topography): An experimental study. J Geographic Informat System. 2017;9:354-371. DOI: 10.4236/jgis.2017.93022.

[17] Smith TB, Smith N, Weleber RG. Comparison of nonparametric methods for static visual field interpolation. Med Biol Eng Comput. 2017;55(1):117-126. DOI: 10.1007/s11517-016-1485-x.

[18] Vicente-Serrano SM, Saz-Sánchez MA, Cuadrat JM. Comparative analysis of interpolation methods in the middle Ebro Valley (Spain): application to annual precipitation and temperature. Clim Res. 2003;24:161-180. DOI: 10.3354/cr024161.

[19] Lee J, Wong D. Statistical Analysis with ArcView GIS. New York: John Wiley Sons. Inc; 2005. ISBN: 978-0-471-46899-8.

[20] Lu H, Cai QY, Wen S, Chi Y, Guo S, Sheng G, et al. Carbonyl compounds and BTEX in the special rooms of hospitals in Guangzhou, China. J Hazard Mater. 2010;178:673-679. DOI: 10.1016/j.jhazmat.2010.01.138.

[21] Toxicity Criteria Database, Cal/EPA, Office of Environmental Health Hazard Assessment, OEHHA Toxicity Criteria Database. http://www.oehha.ca.gov/risk/ChemicalDB/index.asp, 2009.

[22] Kyle AD, Wright CC, Caldwell JC, Buffler PA, Woodruff TJ. Evaluating the health significance of hazardous air pollutants using monitoring data. Public Health Rep. 2001;16:32-44. DOI: 10.1093/phr/116.1.32.

[23] Tecer LH, Tagil S. Spatial and Temporal Variations of Nitrogen Dioxide and Ozone Concentrations Assessment Using a GIS Based Geostatistical Approach in Balikesir, Turkey. 12th International Multidisciplinary Scientific GeoConference, www.sgem.org, SGEM2012 Conference Proceedings/ ISSN 1314-2704, June 17-23 2012;4:411-418. DOI: 10.5593/SGEM2012/S17.V4023.

[24] Wong DW, Yuan L, Perlin SA. Comparison of spatial interpolation methods for the estimation of air quality data. J Expo Anal Environ Epidemiol. 2004;14(5):404-415. DOI: 10.1038/sj.jea.7500338.

[25] Anselin L, Syabri I, Kho Y. GeoDa: an introduction to spatial data analysis. Geogr Anal. 2006;38:5-22. DOI: 10.1111/j.0016-7363.2005.00671.x. 
[26] Anselin L. Local indicators of association-LISA. Geogr Anal. 1995;27:93-115. DOI: 10.1111/j.1538-4632.1995.tb00338.x.

[27] Getis A, Ord JK. The analysis of spatial association by use of distance statistics. Geogr Anal. 1992;24(3):189-206. DOI: 10.1111/j.1538-4632.1992.tb00261.x.

[28] Lee SC, Chiu MY, Ho KF, Zou SC, Wang XM. Volatile Organic Compounds (VOCs) in urban atmosphere of Hong Kong. Atmos Environ. 2002;48:375-382. DOI: 10.1016/S0045-6535(02)00040-1.

[29] Hsieh LT, Yang HH, Chen HW. Ambient BTEX and MTBE in the neighborhoods of different industrial parks in Southern Taiwan. J Hazard Mater. 2006;128:106-115. DOI: 10.1016/j.jhazmat.2005.08.001.

[30] Pekey B, Ozaslan U. Spatial distribution of $\mathrm{SO}_{2}, \mathrm{NO}_{2}$, and $\mathrm{O}_{3}$ concentrations in an industrial City of Turkey using a passive sampling method. Clean. 2013;41:423-428. DOI: 10.1002/clen.201200172.

[31] Hoque RR, Khillare PS, Agarwal T, Shridhar V, Balachandran S. Spatial and temporal variation of BTEX in the urban atmosphere of Delhi, India. Sci Total Environ. 2008;392:30-40. DOI: 10.1016/j.scitotenv.2007.08.036.

[32] Gelencsér A, Siszler K, Hlavay J. Toluene-benzene concentration ratio as a tool for characterizing the distance from vehicular emission sources. Environ Sci Technol. 1997;31:2869-2872. DOI: 10.1021/es970004c.

[33] Liu PWG, Yao YC, Tsai JH, Hsu YC, Chang LP, Chang KH. Source impacts by volatile organic compounds in an industrial city of southern Taiwan. Sci Total Environ. 2008;398(13):154-163. DOI: 10.1016/j.scitotenv.2008.02.053.

[34] Monod A, Sive BC, Avino P, Chen T, Blake DB, Rowland FS. Monoaromatic compounds in ambient air of various cities: a focus on correlations between the xylenes and ethylbenzene. Atmos Environ. 2001;35:135-149. DOI: 10.1016/S1352-2310(00)00274-0.

[35] Truc VTQ, Oanh NTK. Roadside BTEX and other gaseous air pollutants in relation to emission sources. Atmos Environ. 2007;41:7685-7697. DOI: 10.1016/j.atmosenv.2007.06.003.

[36] Yurdakul S, Civan M, Tunce G. Volatile organic compounds in suburban Ankara atmosphere, Turkey: sources and variability. Atmos Res. 2013;120-121:298-311. DOI: 10.1016/j.atmosres.2012.09.015.

[37] Zalel A, Broday DM. Revealing source signatures in ambient BTEX concentrations. Environ Pollut. 2008;156(2):553-562. DOI: 10.1016/j.envpol.2008.01.016.

[38] Mehta D, Nguyen A, Montenegro A, Li ZA. Kinetic study of the reaction of OH with xylenes using the relative rate/discharge flow/mass spectrometry technique. J Phys Chem. 2009;113(46):12942-12951. DOI: 10.1021/jp905074j.

[39] Council Directive 96/62/EC of 27 September 1996 on ambient air quality assessment and management. http://eur-lex.europa.eu/LexUriServ/site/en/consleg/1996/L/ 01996L0062-20031120-en.pdf.

[40] Itano Y, Bandow H, Takenaka N, Saitoh Y, Asayama A, Fukuyama J. Impact of $\mathrm{NO}_{\mathrm{x}}$ reduction on long-term ozone trends in an urban atmosphere. Sci Total Environ. 2007;379:46-55. DOI: 10.1016/j.scitotenv.2007.01.079.

[41] Zabalza J, Ogulei D, Elustondo D, Santamaría JM, Alastuey A, Querol X, et al. Study of urban atmospheric pollution in Navarre (Northern Spain). Environ Monit Assess. 2007;134:137-151. DOI: 10.1007/s10661-007-9605-6.

[42] Saborit JMD, Cano VJE. Field comparison of passive samplers versus UV-photometric analyser to measure surface ozone in a Mediterranean area. J Environ Monit. 2007;9:610-615. DOI: 10.1039/B618075B

[43] Keuken M, Roemer M, van den Elshout S. Trend analysis of urban $\mathrm{NO}_{2}$ concentrations and the importance of direct $\mathrm{NO}_{2}$ emissions versus ozone/NOx equilibrium. Atmos Environ. 2009;43:4780-4783. DOI: 10.1016/j.atmosenv. 2008.07.043.

[44] Wolff GT, Korsog PE. Ozone control strategies based on the ration of volatile organic compounds to nitrogen oxides. J Air Waste Manage Assoc. 1992;42:1173-1177. DOI: 10.1080/10473289.1992.10467064. 